\title{
Assessment of Tritium Activity in Groundwater at the Nuclear Objects Sites in Lithuania
}

\author{
Vigilija Cidzikienè, ${ }^{1}$ Vaidotė Jakimavičiūtè-Maselienè, ${ }^{2,3}$ Raselè Girgždienė,,4 \\ Jonas Mažeika, ${ }^{3}$ and Rimantas Petrošius ${ }^{3}$ \\ ${ }^{1}$ Vilnius Gediminas Technical University, Sauletekio Aleja 11, 10223 Vilnius, Lithuania \\ ${ }^{2}$ Vilnius University, M. K. Čiurlionio Street 21/27, 03101 Vilnius, Lithuania \\ ${ }^{3}$ Nature Research Centre, Akademijos Street 2, 08412 Vilnius, Lithuania \\ ${ }^{4}$ Center for Physical Sciences and Technology, Savanoriu Avenue 231, 02300 Vilnius, Lithuania \\ Correspondence should be addressed to Vigilija Cidzikiené; vigilija.c@gmail.com
}

Received 28 August 2013; Revised 23 January 2014; Accepted 25 January 2014; Published 12 March 2014

Academic Editor: Joonhong Ahn

\begin{abstract}
Copyright (C) 2014 Vigilija Cidzikiene et al. This is an open access article distributed under the Creative Commons Attribution License, which permits unrestricted use, distribution, and reproduction in any medium, provided the original work is properly cited.
\end{abstract}

\begin{abstract}
The assessment of nuclear objects sites in Lithuania, including groundwater characterization, took place in the last few years. Tritium activity in groundwater is a very useful tool for determining how groundwater systems function. Natural and artificial tritium was measured in 8 wells in different layers (from 1.5 to 15 meters depth). The results were compared with other regions of Lithuania also. The evaluated tritium activities varied from 1.8 to $6.4 \mathrm{~Bq} / \mathrm{L}$ at nuclear objects sites in Lithuania and they are coming to background level $(1.83 \mathrm{~Bq} / \mathrm{L})$ and other places in Lithuania. The data show, that groundwater at the nuclear power objects sites is not contaminated with artificial tritium. In this work, the vertical tritium transfer from soil water to the groundwater well at nuclear objects site was estimated. The data show that the main factor for vertical tritium transfer to the well depends on the depth of wells.
\end{abstract}

\section{Introduction}

Lithuania is planning to construct a new nuclear power plant (NPP) nearby the closed one. Lithuanian's obligation to shut down old one was one of the requirements included in the European Union Accession Treaty. Unit 1 of closed NPP was shut down on December 31, 2004, and unit 2 on December 31, 2009. A near surface repository for low and intermediate-level short-lived radioactive waste will be built on the Stabatiskes site in the vicinity of Ignalina NPP during decommissioning works. The disposal capacity can also be used for the waste stored in the temporary repositories of the Ignalina NPP. Engineering barriers are used in the repository for radioactive waste; however, in longterm evolution scenario radionuclides can spread into the environment, extend in the biosphere, and cause (define) the external exposure of the environment due to the natural and premature (prescheduled) degradation of the engineering barriers of the repository [1]. The decommissioning waste, the new NPP sites, and the closed NPP site are located in the north-eastern part of Lithuania on the shore of Lake Druksiai, close to the borders of Latvia and Belarus (Figure 1).

Groundwater characterization is an important issue in the setting process of new NPP and decommissioning of the old NPP's. Groundwater dating is a very useful tool for determining how groundwater systems function $[2,3]$. The radionuclides transport in water systems depends on many factors: the physicochemical condition, $\mathrm{pH}$, salinity, hydrological, biological, and so on.

The tritium in groundwater can be treated as an indicator of radionuclide release from nuclear energy objects. Tritium is a radioactive isotope of the element hydrogen. Tritium occurs naturally in the upper atmosphere when fast neutrons interact with nitrogen. It is also produced during nuclear weapons explosions and commercially in nuclear reactors producing electricity. Anthropogenic tritium sources include 


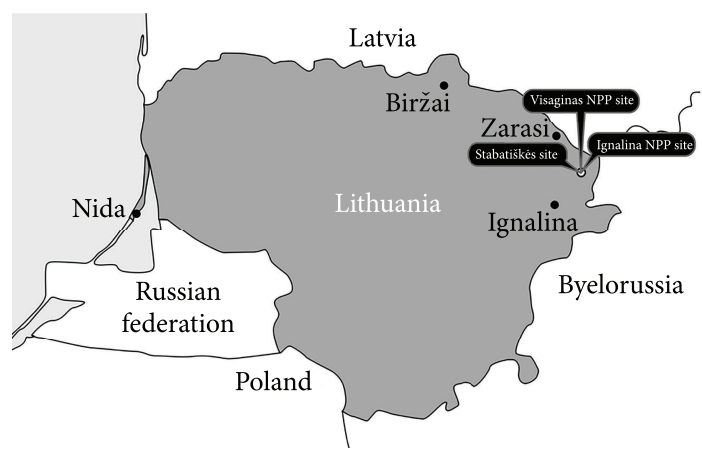

FIgURE 1: The locations of the observation objects sites are Ignalina NPP; Visaginas NPP; Stabatiske; Budiniai; Zarasai; Birzai; Nida.

fallout from nuclear weapons testing, nuclear reactors, future fusion reactors, fuel reprocessing plants, heavy water production facilities and commercial production for medical diagnostics, radiopharmaceuticals, luminous paints, sign illumination, self-luminous aircraft, airport runway lights, luminous dials, gauges and wrist watches, and others [4]. Commercial uses of tritium account for only a small fraction of the tritium used worldwide. Tritium is a pure beta-emitter with a half-life of 12.32 years, a maximum energy of $18 \mathrm{keV}$, and a mean energy of $5.7 \mathrm{keV}$ [5]. The most common form of tritium is in water, since both radioactive tritium and nonradioactive hydrogen react with oxygen in the same way to form water. Tritium replaces one of the stable hydrogen in the water molecule, $\mathrm{H}_{2} \mathrm{O}$, creating tritiated water, which is colorless and odorless. Tritium is a radioactive isotope of hydrogen which occurs in precipitation. In groundwater studies tritium measurements give information on the time of recharge to the system, with the tritium content of precipitation being used to estimate the input of tritium to the groundwater system [6].

Natural tritium production per unit time and per unit area at the earth's surface is estimated to occur at a rate of approximately 0.1 to 1.3 tritium atoms $/ \mathrm{cm}^{2} / \mathrm{s}$, with the most probable values occurring around 0.5 to 1.0 tritium atoms $/ \mathrm{cm}^{2} / \mathrm{s}$ [7-10]. The turnover of tritium is very fast, except where it is fixed in glacier ice or groundwater, and when it is incorporated into organically bound tritium in organisms [11]. The tritium origin and hydrological cycle is presented in Figure 2.

The transfer of tritium as HTO (tritiated water) from soil surface to the groundwater is essentially a process of vertical downward infiltration. This is a simplification of the process because there is also horizontal flow in the aquifer, if a gradient exists, as well as upward flow where the aquifer intersects a surface watercourse, that is, a discharge zone (Figure 2). Both longitudinal and lateral dispersion occurs along the horizontal flow path, so the plume arising from the source area becomes wider, but centre-line concentrations are reduced along the flow path. Tritium concentrations are also reduced by decay along the flow path.

Horizontal flow is the most important for a receptor (i.e., well) in the downgradient direction from an atmospheric source, because the horizontal flow from upgradient may contain higher tritium concentrations than those arising from the air directly above the receptor. In other situations, the transfer from soil water to groundwater may be conservatively represented as a vertical downward infiltration.

Hart [12] assumed a simple vertical downward transport in defining $\mathrm{P}_{3 \text { spw2w }}(\mathrm{L} / \mathrm{L})$, the transfer of radionuclides from soil water to a groundwater well, as follows:

$$
\mathrm{P}_{3 \text { spw2w }}=\exp \left(-\lambda_{r} \cdot T_{r}\right)=\exp \left[-\lambda_{r} \cdot Z_{\mathrm{TOS}} \frac{\left(n+K_{d} \cdot \rho_{b}\right)}{q_{\text {gw.infil }}}\right],
$$

where $T_{r}$ is the travel time from surface soil to well screen (s); $Z_{\mathrm{TOS}}$ the soil depth to the top of the well screen $(\mathrm{m})$; $n$ the effective porosity; $K_{d}$ the partition coefficient of the radionuclide in the soil $\left(\mathrm{m}^{3} / \mathrm{kg}\right) ; \rho_{b}$ the soil bulk density $\left(\mathrm{kg} / \mathrm{m}^{3}\right) ; q_{g w \text {.infil }}$ the infiltration rate $(\mathrm{m} / \mathrm{s}) ; \lambda_{r}$ the radioactive decay rate $(1 / \mathrm{s})$.

In the case of tritium, the $K_{d}$ is zero, since water does not adsorb to soil, and the term $K_{d} \cdot \rho_{b}$ drops from the equation. In the case of tritium, the $K_{d}$ is zero, since water does not adsorb to soil, and the term $K_{d} \cdot \rho_{b}$ drops from the equation.

The effective porosity $(n)$ represents an average for the entire pathway between the ground surface and the intake zone of the well. The soil moisture content can be considered an effective porosity in the unsaturated zone above the water table. The porosity of the most unconsolidated porous media below the water table is in the range of 0.3 to 0.5 .

Background levels of tritium in groundwater can be significant, depending on depth, because tritium inputs from atmospheric deposition have been higher in the past. Tritium levels in global air and precipitation began to increase around 1950 as a result of nuclear weapons testing and peaked in 1963 during the Nuclear Test Ban treaty between the United States and the Soviet Union. They have been decreasing since that that time. Tritium levels in Ottawa precipitation peaked at approximately $600 \mathrm{~Bq} / \mathrm{L}$ in 1963 [13].

Depth profiles of tritium in groundwater usually show a peak at a depth level corresponding to 1963. Retrospective studies in Japan [14] show a tritium peak in precipitation at approximately $100 \mathrm{~Bq} / \mathrm{L}$ in 1963 and a corresponding peak in shallow groundwater (top of saturated zone) at approximately $60 \mathrm{~Bq} / \mathrm{L}$ in 1964. The reduced concentration in groundwater in this zone was attributed mainly to dilution by discharge of deeper uncontaminated groundwater into the top layer of the aquifer. The residence time in the top layer was estimated at 3 years, which is insufficient for appreciable decay of tritium.

According to Lin and Wei [15], groundwater studies in China show tritium in a 1988 core profile peaking at $66 \mathrm{~Bq} / \mathrm{L}$ at a depth of 6-7 m, representing the fallout signature and a 1997 core profile at the same location peaking at $27 \mathrm{~Bq} / \mathrm{L}$ at a depth of $10 \mathrm{~m}$ [15]. The difference in concentration is partly due to decay and partly due to longitudinal dispersion during vertical migration. The rate of vertical migration was estimated at 0.25 to $0.30 \mathrm{~m} / \mathrm{a}$. A similar study in France [11] shows tritium in three 2002 core profiles peaking at a depth of $9-10 \mathrm{~m}$, representing the fallout signature. The average infiltration rate over the 1963-2002 period was estimated at 0.20 to $0.21 \mathrm{~m} / \mathrm{a}$ based on the peak centre of mass. 


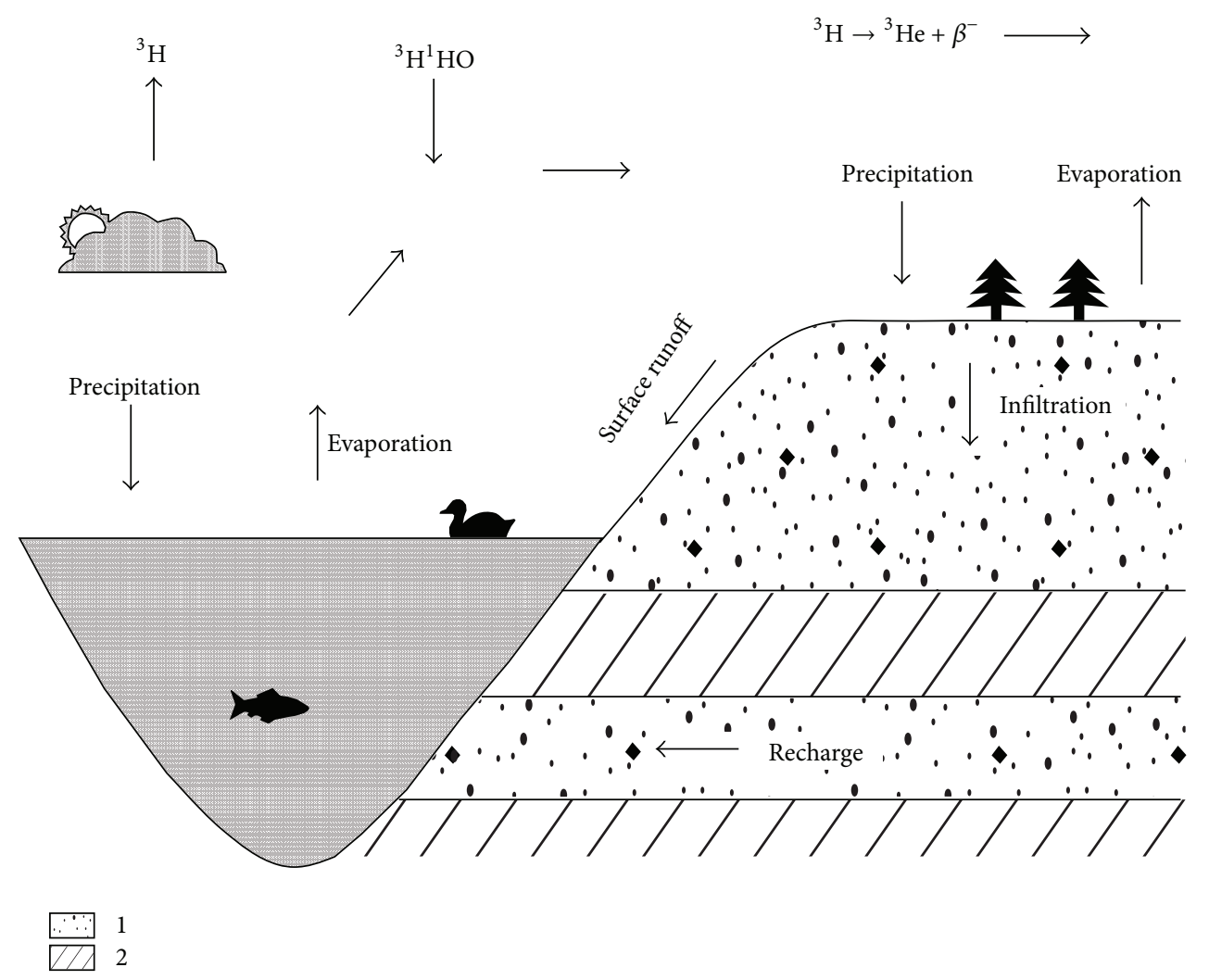

FIGURE 2: The tritium origin and hydrological cycle: 1-aquifers; 2 -aquitards.

The nuclear objects proposed to be constructed in Visaginas and both potential sites are located next to the former, closed Ignalina nuclear power plant. This paper deals with the assessment of the tritium activity in groundwater at the nuclear object sites.

\section{Location}

The nuclear objects in Lithuania are concentrated in the eastern part. There are Ignalina and Visaginas NPP's, planned radioactive waste storage facilities. This area surface, down to $4-12 \mathrm{~m}$, is composed of till body (sandy loam and clayey loam) of low permeability. A thin (0.5-1.5 m) layer of glaciofluvial sand lies at the surface in many places of Stabatiske site and NPP sites as well. Groundwater (perched) accumulates in it only seasonally. This layer as a whole is drained by local boggy depressions. The first continuous semiconfined aquifer is overlain by the $5-9 \mathrm{~m}$ thick layer (sandy loam and clayey loam). Groundwater is at a depth of 5-10 m (at altitude of 149.99-147.04 $\mathrm{m}$ a.s.l.; the long-term water level in Lake Druksiai is $141.6 \mathrm{~m}$ a.s.l.). The aquifer has little or no connection with the boggy local depressions; it is drained to a larger extent by Lake Druksiai.

The hydraulic conductivity of the aquifer, depending on the grain size distribution of sand material, ranges from $5.3 \cdot 10^{-5}$ to $3.1 \cdot 10^{-4} \mathrm{~m} / \mathrm{s}$, and the hydraulic gradient is $0.009-0.01$. A hydraulic head around the site ranges from 147 to $154 \mathrm{~m}$ a.s.l. Hydraulic conductivity of low permeable layers ranges from $3.5 \cdot 10^{-9}$ to $1.5 \cdot 10^{-7} \mathrm{~m} / \mathrm{s}$. A confined low permeable layer from below occurs at altitude of $124 \mathrm{~m}$ a.s.l. and represents continuous aquitard [16].

The systematic investigations of groundwater system have been begun before Ignalina NPP construction in 1983.

\section{Methodology}

The activity of tritium in the groundwater was measured in many observation wells constructed in the region of Ignalina NPP. Water samples were taken from different layers (from 1.5 to 15 meters depth). Thus, the water samples of all observations points were measured several times. Tritium activity was measured with the method of liquid scintillation beta-spectrometry. The most systematic observations were fulfilled in the wells number 1429 and 1431 of Ignalina NPP site in 2002-2004, in Stabatiske site (one observation well) since 2005. Visaginas NPP site (5 observation wells) was investigated 2011.

The tritium measurements in groundwater have been performed in four different regions of Lithuania also; two of them belong to the eastern part of Lithuania: Zarasai, Ignalina regions. In 1991-1995 tritium activity concentration was observed in groundwater of karst region, Birzai (North part of Lithuania). The tritium activity concentration in Nida region (western part of Lithuania) was observed in 1983-2001. 


\section{Results and Discussion}

The magnitude of the measured tritium value on the nuclear object territories could have been influenced by global sources, local releases from the previously operated Ignalina NPP, precipitation input, soil moisture transfer rate, groundwater residence time, and so forth. Although these parameters affect distribution of tritium in groundwater, their impact on the tritium at all studied sites is rather uniform due to a relatively small distance between these sites.

The tritium activity concentration in groundwater wells of closed Ignalina NPP varied from $1.6 \mathrm{~Bq} / \mathrm{L}$ in well number 1429 to $5.3 \mathrm{~Bq} / \mathrm{L}$ in the same well (Figure 3). The maximum of tritium activity concentration in water was observed in 19891991 and they are coming to background level.

According to Mazeika (1997), the annual average tritium activity concentration in precipitation of Ignalina NPP region was accounted-16.6 TU (1.83 Bq/L) [17]. The tritium activity concentration was detected $1.29 \mathrm{~Bq} / \mathrm{L}$ in winter time and $2.22 \mathrm{~Bq} / \mathrm{L}$ in summer time. The similar tritium activities were determined in other Lithuania cities also.

The tritium activity concentration in site of planned nearsurface radioactive waste repository (Stabatiske site) was measured in the water samples collected in more than 20 observation wells. In the present work are given the results of tritium activity investigations in the well number 6 of Stabatiske site because of the largest number of measurements The tritium activity concentration varies from $0.1 \mathrm{~Bq} / \mathrm{L}$ in 18.05.2006 to $1.7 \mathrm{~Bq} / \mathrm{L}$ in 15.01.2006 (Figure 3).

The last tritium activity concentrations measurements in Visaginas NPP site indicate the downtrend of tritium activity concentration in the groundwater. The tritium activity concentration in groundwater wells varies from $2.6 \mathrm{~Bq} / \mathrm{L}$ to 6.4 Bq/L in 2011 and from $0.21 \mathrm{~Bq} / \mathrm{L}$ to $1.52 \mathrm{~Bq} / \mathrm{L}$ in 2013 (Figure 3); that is, tritium activity concentration in this site oscillates between background level $(1.3 \mathrm{~Bq} / \mathrm{L})$.

The measurements were done from 3 to 39 times and the measurements errors of Ignalina 1429 and 1431 wells are presented in Figure 3. The error of measurements from activity concentration was estimated and consists of 10 percent. The measurements errors are shown (Figure 4) of the two these wells where most of measurements have been done. In the other regions of Lithuania the tritium activity concentration was measured in the different periods. The tritium activity in the northern (Karajimiskis) and in the north-eastern (Sakiai, Budiniai) Lithuania varies from $1.5 \mathrm{~Bq} / \mathrm{L}$ to $3.2 \mathrm{~Bq} / \mathrm{L}$. In the western Lithuania the tritium activity concentration is slightly lower and reaches $2 \mathrm{~Bq} / \mathrm{L}$ (Figure 5).

The tritium activity concentration in the wells of above mentioned regions of Lithuania is about background level $(1.3 \mathrm{~Bq} / \mathrm{L})$. The measurement values of tritium do not exceed the rate as regulated by the Lithuanian hygiene norm $\mathrm{HN}$ $24: 2003$ "Requirements for Safety and Quality of Drinking Water" (100 Bq/L) [18].

The limits of tritium in groundwater are not established as it is depends on water "age" (the less the water that enters from the surface to groundwater, the less the tritium activity in groundwater).

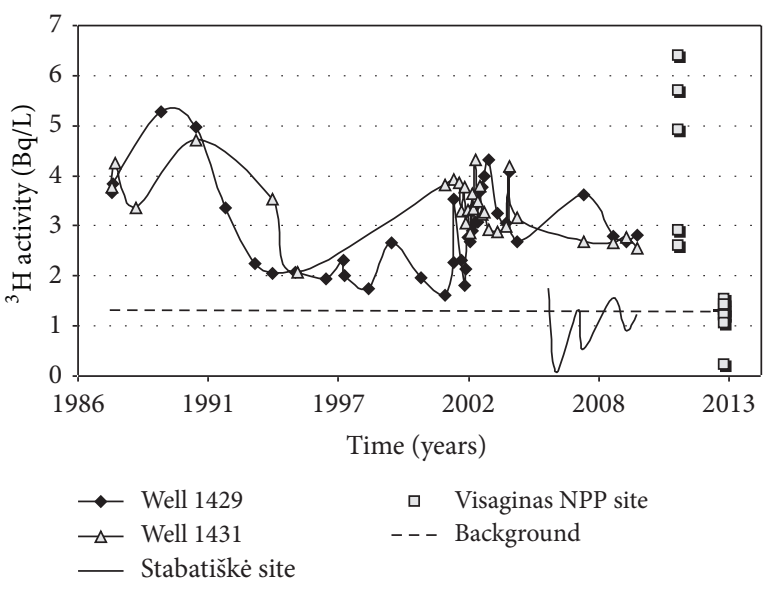

FIgURE 3: Tritium distribution in groundwater of Ignalina NPP region.

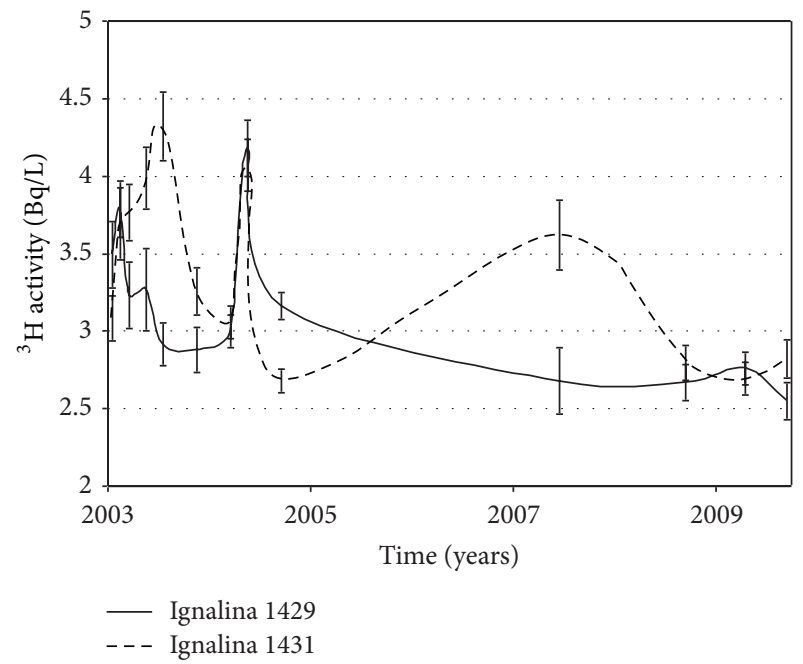

FIgURE 4: The measurements results and errors (1429, 1431 Ignalina wells).

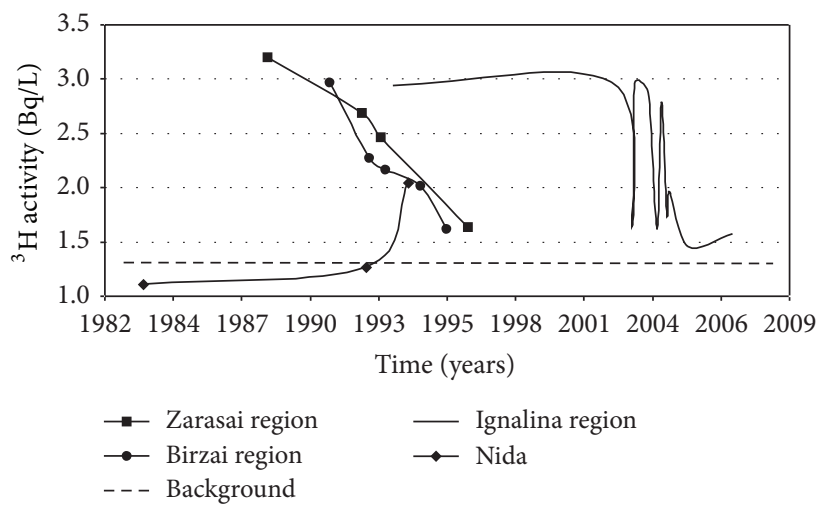

FIgURE 5: Tritium distribution in groundwater of different regions of Lithuania. 


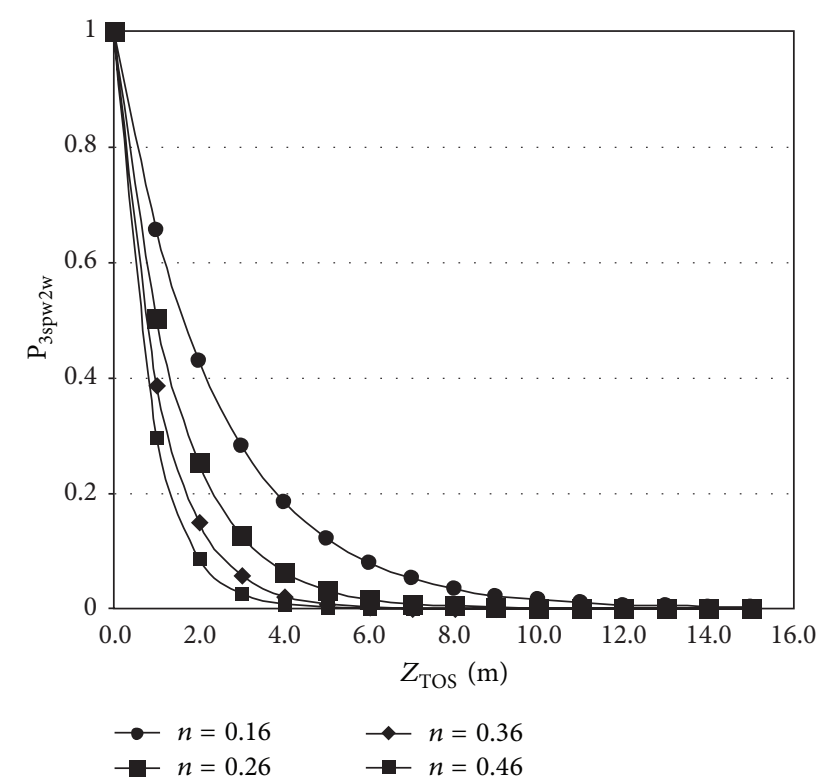

FIGURE 6: Variability of vertical tritium transfer versus effective porosity and soil depth, when infiltration rate is fixed (6.7 . $\left.10^{-10} \mathrm{~m} / \mathrm{s}\right)$.

In this work the vertical tritium transfer from soil water to the groundwater well $\left(\mathrm{P}_{3 \mathrm{spw} 2 \mathrm{w}}\right)$ at nuclear objects site was estimated also (1). The estimated parameters of soils were used. The effective porosity is an average value for the entire pathway between the ground surface and the intake zone of the well, which includes the zones above and below the water table. The effective porosity in this area varies from 0.16 to $0.46[19,20]$, the radioactive decay rate of tritium is $1.77 \cdot 10^{-9} \mathrm{l} / \mathrm{s}$, the infiltration rate $6.7 \cdot 10^{-10} \mathrm{~m} / \mathrm{s}$, and the soil thickness from the surface to the well intake zone varies from 1.5 to $15 \mathrm{~m}$. Effective depth of well intake zone is $80 \%$ of total well depth. This assumption implies that only top part of well supplies water to the well [12]. The infiltration rate was calculated couple of times according to tritium and volumetric moisture data [19].

The parameter $\mathrm{P}_{3 \text { spw2w }}$ shows vertical tritium transfer to the well and describes what part of tritium could reach well water. By taking advantage of earlier identified parameters in investigated sites the calculations showed that the vertical tritium transfer can vary from 0.655 to $1.2 \cdot 10^{-8}$ (Figure 6) at different effective porosity and soil depth. The vertical tritium transfer depends on the soil thickness and effective porosity and groundwater in the region of nuclear sites could be enriched by tritium activity concentration equal of atmospheric tritium. The results in Figure 6 show that tritium vertical downward transport depends on effective porosity, and the tritium activity would not reach the groundwater.

Tritium values of nuclear object sites in Lithuania were insignificantly higher in comparison with the tritium values in other towns of Lithuania (Figure 5). Results of investigations clearly demonstrate that no local radiometric anomaly exists at the sites.

\section{Conclusions}

The obtained results of the tritium activity concentration at the nuclear power object sites show that the groundwater is not contaminated with artificial radionuclides. The evaluated tritium activities varied from 1.8 to $6.4 \mathrm{~Bq} / \mathrm{L}$ at nuclear object sites in Lithuania and they are coming to background level $(1.83 \mathrm{~Bq} / \mathrm{L})$. In the western part of Lithuania tritium activity is less and varies from $1.1 \mathrm{~Bq} / \mathrm{L}$ to $2.0 \mathrm{~Bq} / \mathrm{L}$. Tritium activity concentration does not exceed the rate as regulated by the Lithuanian hygiene norm HN $24: 2003$ "Requirements for Safety and Quality of Drinking Water" with a value of $100 \mathrm{~Bq} / \mathrm{L}$ (Figure 5). The data analysis demonstrates that no local radiometric anomaly existed at the NPP sites.

Variability of vertical tritium transfer versus effective porosity and soil depth was also estimated. The results (Figure 6) show that tritium vertical downward transport is more dependent on the soil depth than the effective porosity. Vertical tritium transfer is higher near surface.

\section{Conflict of Interests}

The authors declare that they have no conflict of interests regarding the publication of this paper.

\section{References}

[1] J. Alioncik, I. Bataitiene, and D. Butkus, "Radionuclide distribution in the soil on the stabatishkes site in the vicinity of the ignalina NPP," Science-Future/Mokslas_Lietuvos Ateitis, vol. 2, no. 5, pp. 9-16, 2010.

[2] I. M. Mufid al-hadithi, D. C. Singhal, B. Kumar, M. S. Rao, and S. K. Verma, "Groundwater resources evaluation in the Piedmont zone of Himalaya, India, using Isotope and GIS techniques," Journal of Spatial Hydrology, vol. 6, no. 1, pp. 105-119, 2006.

[3] F. J. Pearson and B. B. Hanshaw, "Sources of dissolved carbonate species in groundwater and their effects on carbon-14 dating," in Isotope Hydrology, IAEA, 1970.

[4] D. Galeriu, R. Heling, and A. Melintescu, "The dynamics of tritium-including OBT-in the aquatic food chain," Fusion Science and Technology, vol. 48, no. 1, pp. 779-782, 2005.

[5] L. L. Lucas and M. P. Unterweger, "Comprehensive review and critical evaluation of the half-life of tritium," Journal of Research of the National Institute of Standards and Technology, vol. 105, no. 4, pp. 541-549, 2000.

[6] A. Onugba and H. O. Aboh, "The tritium content of precipitation and groundwater at Yola, Nigeria," Science World Journal, vol. 4, no. 2, pp. 23-28, 2009.

[7] D. G. Jacobs, "Sources of tritium and its behaviour upon release to the environment," AEC Critical Review Series TID-24635, 1968.

[8] UNSCEAR (United Nations Scientific Committee on the Effects of Atomic Radiation), "Sources and Effects of Ionizing Radiation. United Nations Scientific Committee on the Effects of Atomic Radiation," Report to the General Assembly, with Annexes, in United Nations Sales Publication E.77.IX.I, New York, NY, USA, 1977.

[9] A. T. Wilson and G. J. Ferguson, "Origin of terrestrial tritium," Geochim Cosmochim Acta, vol. 18, no. 3-4, pp. 273-277, 1960.

[10] A. Zahn, V. Barth, K. Pfeilsticker, and U. Platt, "Deuterium, Oxygen-18, and Tritium as tracers for water vapour transport 
in the lower stratosphere and tropopause region," Journal of Atmospheric Chemistry, vol. 30, no. 1, pp. 25-47, 1998.

[11] N. Baran, J. Richert, and C. Mouvet, "Field data and modelling of water and nitrate movement through deep unsaturated loess," Journal of Hydrology, vol. 345, no. 1-2, pp. 27-37, 2007.

[12] D. Hart, "Derived Release Limits Guidance CANDU Owners Group Inc," Tech. Rep. COG-06-3090-R2-I, 2008.

[13] R. D. Mutch Jr. and J. D. Mahony, "A study of tritium in municipal solid waste leachate and gas," Fusion Science and Technology, vol. 54, no. 1, pp. 305-310, 2008.

[14] K. Miyamoto, K.-I. Kimura, and S. Hongo, “Transfer model of tritium in a local hydrosphere," Fusion Technology, vol. 28, no. 3, pp. 910-917, 1995.

[15] R. Lin and K. Wei, "Tritium profiles of pore water in the Chinese loess unsaturated zone: implications for estimation of groundwater recharge," Journal of Hydrology, vol. 328, no. 1-2, pp. 192-199, 2006.

[16] V. Jakimaviciute-Maseliene, J. Mazeika, and D. Baltrunas, "Safety assessment of the low and intermediate level radioactive waste near-surface repository for Stabatiske site (Lithuania)," Lithuanian Journal of Physics, vol. 47, no. 4, pp. 503-512, 2007.

[17] J. Mazeika, Radionuclides in Geoenvironment of Lithuania, Vilnius, Lithuania, 2002.

[18] Lithuanian Hygiene Norm HN 24:2003, Requirements For Safety and Quality of Drinking Water, 2003.

[19] Water flow analysis and radionuclide migration in near-surface repository, Scientific Report, Institute of Geography and Geology, Vilnius, Lithuania, 2006.

[20] Hydrogeological description and analysis report, version 2, Issue 1, Nature Research Centre, Vilnius, Lithuania, 2012. 


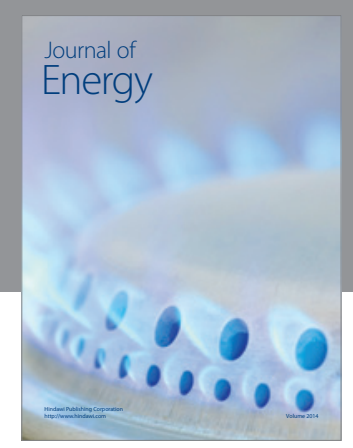

Journal of

Industrial Engineering
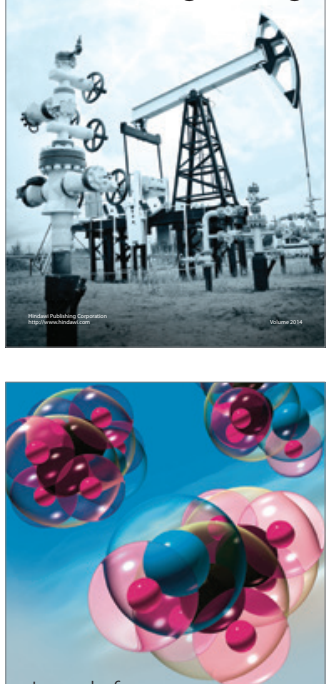

Fuels
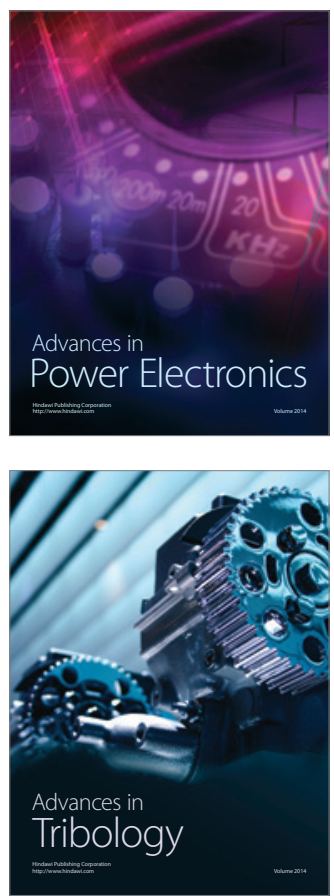

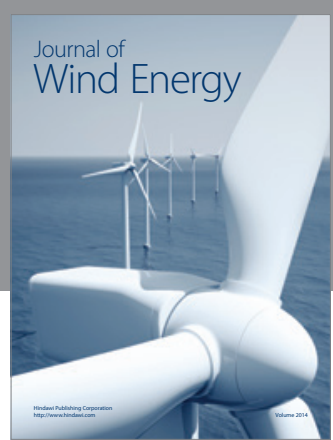

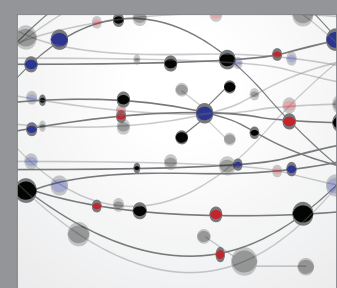

The Scientific World Journal

Submit your manuscripts at http://www.hindawi.com

Journal of

Structures
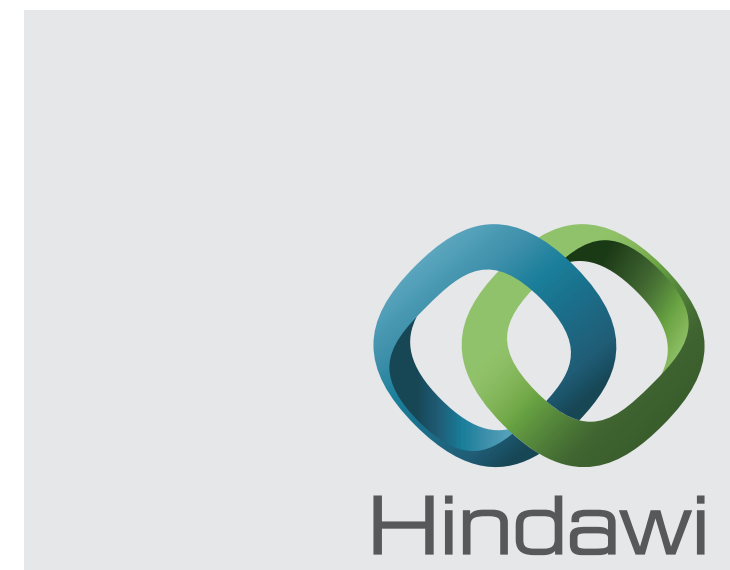

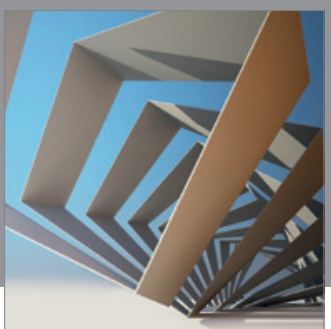

Rotating

Machinery
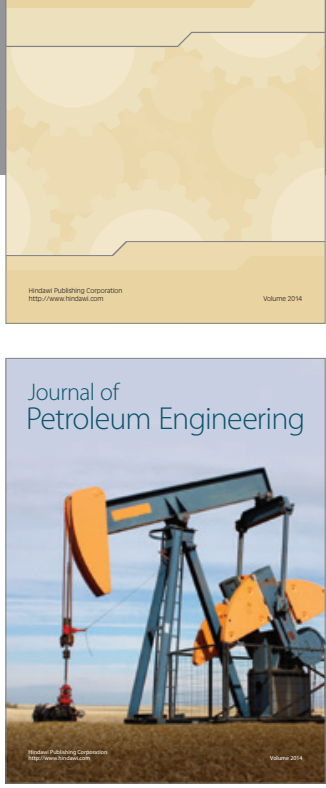

Journal of

Solar Energy
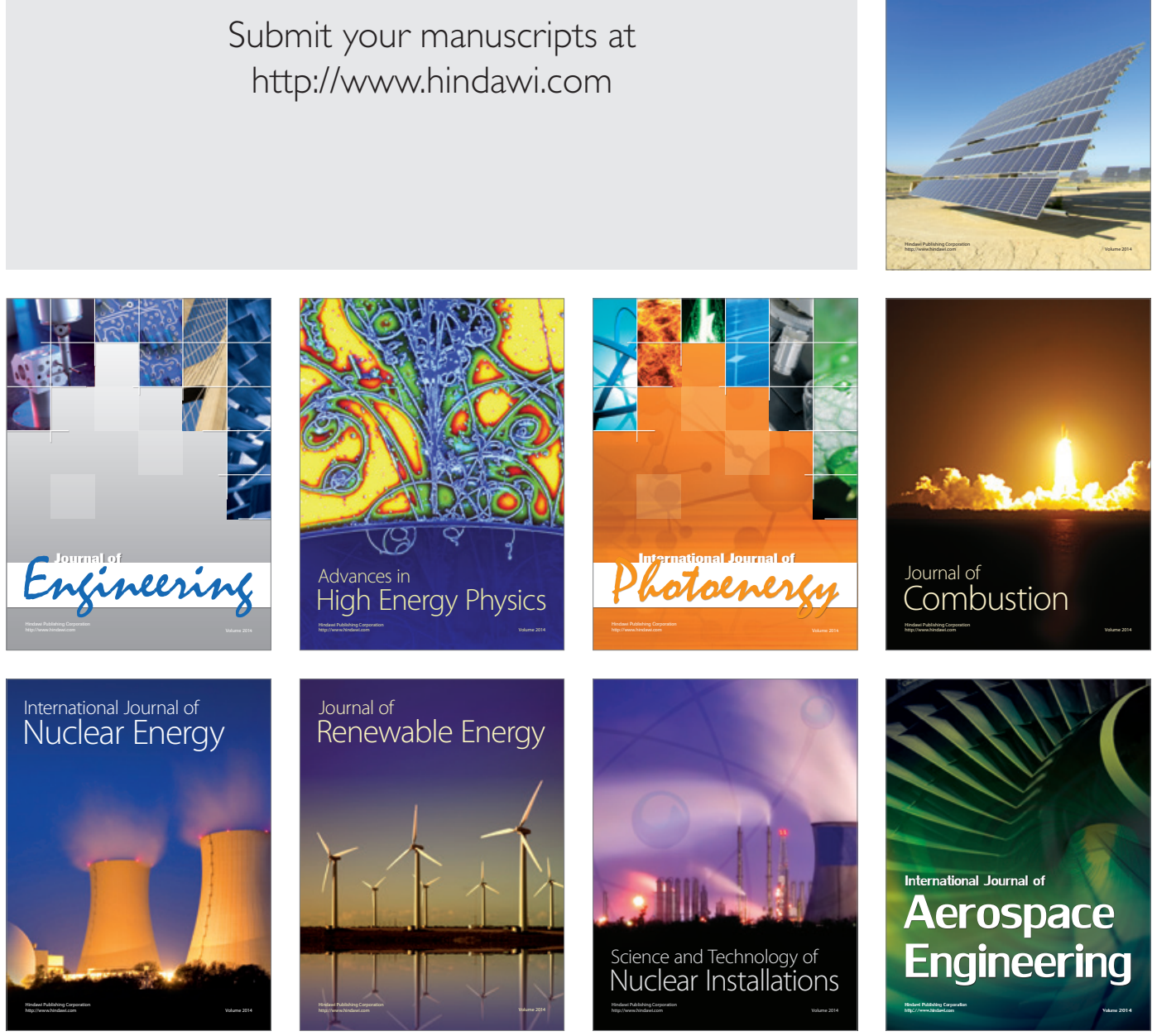